\title{
Preserving the Global Nuclear Order: The Trident Agreements and the Arms Control Debate, 1977-82
}

The Trident negotiations were a pivotal moment in establishing the US-UK nuclear relationship as an accepted element of the global nuclear order. The Trident agreements marked the first supply of a US delivery system to the UK since the signing of the Nuclear Non-Proliferation Treaty and the development of Superpower arms control. In turn, the development of these agendas in the international sphere influenced Anglo-American discussions on the replacement to Polaris. The Carter White House procrastinated on the provision of Trident due in part to their concerns over the political ramifications for their wider non-proliferation and arms control goals. However, fortuitously for the UK's nuclear programme, US-UK discussions on the replacement to Polaris coalesced with the reorientation of US foreign policy towards containment of the Soviet Union under Jimmy Carter and then Ronald Reagan - enabling the finalisation of the sale of Trident to the UK. As such, the status of the US-UK nuclear relationship as a broadly accepted element of the global nuclear order is a legacy of the 'long 1970s' alongside the early Cold War.

Keywords: Thatcher, Reagan, Carter, Anglo-American, US-UK Relations

The United Kingdom is technically dependent on the United States for the maintenance of its advanced nuclear capability. Indeed, US assistance has been crucial to the continuation of the UK's nuclear system since 1960 when the Macmillan government cancelled the country's last indigenous missile, Blue Streak, following President Dwight Eisenhower's offer to supply the UK with the Skybolt missile. ${ }^{1}$ Thenceforth Britain entered a 'new 
paradoxical phase' in its nuclear policy; British technical dependence upon the US would preserve Britain's 'independent deterrent'. ${ }^{2}$ When the US cancelled the Skybolt programme in 1962, the Kennedy administration agreed to supply the Polaris SubmarineLaunched Ballistic Missile System. ${ }^{3}$ Then in July 1980, the United Kingdom and the United States signed the Trident $\mathrm{C}_{4}$ agreement, which agreed on the sale of US Trident $\mathrm{C}_{4}$ missiles to the UK. Following President Ronald Reagan's decision to replace the Trident $\mathrm{C}_{4}$ missile with the Trident D5 system in March 1982, the UK and US governments signed the Trident D5 agreement.

Some historians have stressed the history of US-UK nuclear relations, in particular the precedent of two earlier inter-governmental agreements between the US and UK, the 1958 Mutual Defence Agreement and Polaris Sales Agreement, as a means to understanding the Trident agreements. ${ }^{4}$ Whilst this perspective has merit, it can also lead to tendentious analysis that underplays the role of agency and contingency; few things in history, if any, are inevitable. As is widely agreed amongst historians in the field, at the core of the US-UK nuclear relationship rests mutual interests. 5 The closeness, or otherwise, of AngloAmerican nuclear cooperation at any given point of time rests principally on the alignment of each nation's interests. Due to a broad commonality in strategic concerns, particularly during the Cold War, there was a good deal of continuity in the US-UK nuclear relationship. However, at the same time, there were also moments of acute tension and dispute. ${ }^{6}$ Subsequently, historians like John Baylis and Andrew Priest have highlighted the frequent renegotiation of the relationship, in accordance with the dynamics of mutual interests. ${ }^{7}$ 
Compared to Anglo-American nuclear cooperation in the early Cold War, the relationship in the 'long 1970 ' $^{\text {' has received relatively little scholarly attention. }}{ }^{8}$ Given the importance of mutual interests to US-UK nuclear cooperation, detailed study of this era is important for understanding the maintenance of the Anglo-American nuclear relationship into the present era. The Trident agreements, in particular, advanced that relationship. The Trident negotiations occurred at a time of strategic reorientation by the United States. The United Kingdom's efforts to replace its Polaris system coincided with an evolution of USSoviet thinking in arms control that was transformative for the Cold War nuclear order. The late 1970s saw the end of détente, followed by the rekindling of the Cold War with a renewed stand-off between the United States and the Soviet Union. The impact of these wider US strategic concerns on the Trident negotiations has yet to be the focus of detailed archival study. ${ }^{9}$ As such to deepen understanding of the maintenance of the AngloAmerican nuclear relationship in the 'long 1970s', this article explores the interrelationship between US-UK nuclear cooperation and US policy on arms control throughout the Trident negotiations.

This analysis reveals how the evolution of US thinking on détente and arms control influenced the UK's efforts to replace Trident and caused concern for the British government over the future of their nuclear programme. Washington was willing to assist with the replacement of Polaris if it did not interfere with wider US foreign policy goals. For the Carter White House, as they tried to move beyond an American foreign policy centred on containment, the maintenance of the UK's deterrent was not a priority. At the Guadeloupe summit in January 1979, Jimmy Carter told the British Prime Minister, James 
Callaghan, that he would consider the supply of Trident $C_{4}$ to the UK. However, notwithstanding Carter's forthcoming response, throughout 1979 and early 1980 the British government remained uncertain that the Trident $\mathrm{C}_{4}$ agreement would come to fruition. This was because of the Carter administration's concerns over the ramifications of the sale for progress on the Strategic Arms Limitation Talks (SALT), NATO consensus on the dualtrack policy, and Carter's re-election.

Throughout this period, the Carter White House struggled to resolve the political dilemmas that certain contradictions between their commitment to nuclear arms control, NATO cohesion and US-UK nuclear cooperation raised. Their solution was to delay selling Trident. Fortuitously for the British government in 1980, due to the White House's hardened approach to the Soviet Union following the invasion of Afghanistan and the end of détente, these dilemmas over the supply of Trident abated, and the deal was finalised in July 1980. In contrast, the Reagan administration's policy on arms control in their first years in office meant that their agreement to supply the $\mathrm{D}_{5}$ came swiftly. For the nascent Reagan White House, the supply of Trident raised no dilemmas for its wider foreign policy goals as they aimed to counter the Soviet Union through increasing the nuclear and conventional strength of the West.

In turn, the Trident negotiations shaped the contemporary nuclear order. The Trident agreements were the first supply of a US delivery system to the UK since the signing of the Nuclear Non-Proliferation Treaty in 1968 and the development of Superpower arms control. The agreements thereby reinforced the US-UK nuclear relationship as an acceptable element of the global nuclear order. As this article demonstrates, the US supply 
of a delivery system was contingent upon a number of concurrent global issues such as arms control. The eventual outcome was due in part to the evolution of the wider international environment. As such, the continuation of the US-UK nuclear relationship into the post-Cold War era is a legacy of developments in the 'long 1970s', alongside USUK nuclear cooperation in the Second World War and the early Cold War.

In December 1977, a British Cabinet committee met to discuss the replacement of the Polaris nuclear system. A decision needed to be made in the coming years as, while Polaris would remain operative until about 1993, a successor system could take up to fifteen years to develop. ${ }^{10}$ The Cabinet Committee quickly concluded that they should 'probably... rule out the idea of a wholly British ballistic missile on grounds both of capability and cost'." This left Britain with, primarily, three remaining options, which were all, to an extent, reliant upon US cooperation: the purchase of US Trident $\mathrm{C}_{4}$ missiles; the replacement of Polaris with cruise missiles; or Anglo-French cooperation, which, under the terms of the 1958 Mutual Defence Agreement, would likely require US agreement due to extensive American assistance with the UK's weapon and propulsion technology. ${ }^{12}$

In 1977, the UK government feared that White House commitment to arms control could complicate their efforts to replace Polaris; a problem that the UK Prime Minister Harold Macmillan had not faced when he secured President John F. Kennedy's agreement to sell the Polaris system in $1962 .{ }^{13}$ On entering the White House in January 1977, Jimmy Carter had a bold vision for the global nuclear order. He had campaigned on a platform of using arms control talks to achieve deep cuts in US and Soviet nuclear capability and 
pledged to achieve 'a new and genuine détente'. ${ }^{14}$ The Soviets outright rejection of the 'deep cuts' proposal in March 1977 tempered Carter's ambitions. ${ }^{15}$ Nevertheless, the Carter administration remained committed to the SALT process. Consequently, John Hunt, UK Cabinet Secretary, informed Callaghan in 1977 that he foresaw that US arms control negotiations 'could have implications for each' of the Polaris successor options, and 'could be especially significant for United States cooperation'. ${ }^{16}$

In February 1978, the UK government commissioned Anthony Duff, Deputy UnderSecretary of State at the Foreign Office, and Ronald Mason, Chief Scientific Adviser at the Ministry of Defence (MOD), to produce a study that would consider the 'principal options' for the replacement of Polaris. ${ }^{17}$ In December 1978, the resultant Duff-Mason report was ready for ministerial consideration. The report favoured the Trident $\mathrm{C}_{4}$ system with MIRV as the successor to Polaris. A multiple independently targetable re-entry vehicle (MIRV) payload for a ballistic missile contains several warheads with each one able to strike separate pre-determined targets. Such a system would enhance Britain's first-strike proficiency, provide greater damage per missile payload, and reduce the effectiveness of anti-ballistic missile systems. For these reasons, the authors of the Duff-Mason report felt that a MIRV system, such as the Trident $\mathrm{C}_{4}$, better fulfilled the 'Moscow criterion'; a guiding principle in UK nuclear strategy that Britain's nuclear 'deterrent' should be able to defeat ballistic missile defences around Moscow. ${ }^{18}$ Moreover, in light of the lessons of Chevaline and the huge additional expenditure of an independent system, Duff and Mason thought that there were 'great technical, operational and logistic advantages' to the Trident $\mathrm{C}_{4}$ as it was 'a system in service with the US Navy'. ${ }^{19}$ 
Duff and Mason were relatively optimistic that the US would agree to assist the UK's efforts to replace Polaris. In November 1977, Carter had assured the British of the United States' 'continuing self-interest... in the maintenance of the United Kingdom's independent nuclear capacity'. ${ }^{20}$ Carter made this assurance alongside his ambitious vision to pursue significant reductions in Soviet and US nuclear capability and nuclear non-proliferation. ${ }^{21}$

In order to understand this seemingly contradictory position, it is necessary to think of the UK's nuclear programme within the wider framework of US non-proliferation and Cold War strategy. Through the provision of a replacement American missile system, the UK's nuclear programme remained technically dependent upon the US, providing the US with a degree of control over Britain's nuclear policy. ${ }^{22}$ Without US support, the UK government would likely pursue an independent delivery system. This would reduce the UK's conventional defence expenditure and thereby undermine Western efforts to counter the Soviet Union. Furthermore, the UK's nuclear capability reinforced the credibility of the US nuclear umbrella to Europe through the commitment of Britain's nuclear force to NATO and by providing a second centre of decision-making. This, in turn, stemmed further proliferation. ${ }^{23}$ As such, Duff and Mason foresaw that continued US-UK nuclear cooperation 'would involve least risk to the US commitment to the defence of Europe'. ${ }^{24}$ This was a key point of consideration for the Carter administration. Since the President's election, the White House had struggled to ameliorate doubts in the US nuclear umbrella amongst Western governments. These increased doubts were due to uneasiness about USUSSR strategic parity at the international level, alongside Soviet deployment of the SS-2o. This medium-range missile was not included within the SALT framework, but its 
deployment arguably shifted the military balance in Europe towards the USSR. ${ }^{25}$

Duff and Mason were also optimistic about the supply of Trident $\mathrm{C}_{4}$ due to US efforts to abate British concerns over possible restrictions in the SALT II treaty. Throughout the SALT II process, the Soviets had argued that the US could circumvent the qualitative restrictions in the treaty by secretly transferring forbidden weapons systems or military technologies to its NATO allies. In order to alleviate these concerns, the final treaty included a non-circumvention clause, whereby the US and USSR agreed not to circumvent the provisions of the agreement 'through any other state'. ${ }^{26}$ However, this, in turn, had raised the concerns of the United States' allies in Europe that the Soviets could use the noncircumvention clause to argue that US defence cooperation with its NATO allies broke the spirit of the agreement. ${ }^{27}$ In particular, British officials were concerned about the impact of any non-circumvention clause on their efforts to replace Polaris. ${ }^{28}$ In 1977, John Hunt foresaw that any non-circumvention provision was 'liable to give the Russians a peg on which they can hang claims, however unjustified, that the agreement is being infringed'.29 To maintain alliance support for SALT, and clarify the meaning of the non-circumvention treaty publicly, in March 1978 the White House decided that they would release an interpretive statement on the consequences of a non-circumvention clause for US cooperation with allies, at the same time as the signing of SALT II. $3^{\circ}$ Duff and Mason felt that these actions resolved many of Britain's fears about the non-circumvention clause. Indeed, they noted that Harold Brown, US Secretary of Defense, had explicitly stated in a Senate ratification meeting that 'the US was allowed under the interpretive statement to provide the Allies with modernised forces along the lines of the Cruise Missile and Trident 
submarines'.$^{11}$

Nevertheless, Duff and Mason warned that, even without specific restrictions, the SALT process could influence Britain's efforts to replace Polaris due to the need for the US to consider 'the political implications for SALT'. ${ }^{32}$ The supply of a MIRV system could be one such area for political consideration. Concerns that the US would not provide the MIRVed Poseidon system had partly motivated British development of Chevaline. The Nixon administration feared that the provision of such a system, which would have vastly improved Britain's first strike capability, could undermine SALT I negotiations and thereby encounter congressional dissent. ${ }^{33}$ The provision of MIRV was now even more politically salient in the SALT process.

The key provision of the final SALT II agreement was an aggregate ceiling for strategic launchers of 2,250 for each side. This included a 1,320 MIRV sub-limit consisting of no more than 820 MIRVed inter-continental ballistic missile systems and 120 strategic bombers equipped with cruise missiles. During negotiations, the Soviets argued that the national nuclear forces of Britain and France, as well as forward-based nuclear forces in Western Europe, tilted the strategic balance towards the West. ${ }^{34}$ Therefore, the Soviets wanted British and French systems included in the agreed limits as well as a non-transfer clause. Washington rejected these demands as they believed that pitting Soviet nuclear forces against all Western allied forces would undercut the US 'deterrent' and raise allied doubts in the nuclear umbrella. The NATO alliance strongly supported the United States long-standing rejection of Soviet pressure to include non-central systems. 35 In negotiations for SALT III, Duff and Mason expected the US to continue to resist Soviet pressure for the 
inclusion of British and French systems. However, in the declaration of principles for SALT III, the US and the Soviet Union had committed to 'seeking... significant and substantial reductions in strategic system numbers'. ${ }^{36}$ The supply of a MIRV system would provide the British with a sharp increase in capability and thus could intensify feelings in Moscow that UK and French systems should be included in SALT III and could consequently stem progress. As such, given the political salience of MIRV and British systems within SALT, Duff and Mason thought it 'difficult to judge whether the US would offer their MIRV capability'.37

If the US refused to sell Britain a MIRV system, this would create difficulties for the replacement of Polaris. The MIRV capability was integral to the design of the Trident $\mathrm{C}_{4}$. The removal of this capability 'would entail a major re-design and re-testing programme, leading to a missile degraded in performance and unique to Britain'.$^{38}$ Such a redesign would increase the missile costs by 'at least double those of Trident'.39 Duff and Mason concluded that there would need to be further exploration of Britain's inferior alternatives if the Carter administration refused to supply Trident $\mathrm{C}_{4}$ with MIRV.40 The report clarified that inquiries to Carter over his willingness to provide Trident $\mathrm{C}_{4}$ with MIRV was essential to progress on Polaris replacement. Subsequently, when a Cabinet committee discussed the report on 21 December 1978, Callaghan decided that he would utilise the upcoming Guadeloupe summit to inquire about the President's attitude vis-à-vis the supply of Trident. ${ }^{41}$

On 5-6 January 1979, Jimmy Carter, James Callaghan, Helmut Schmidt, the German Chancellor, and Valéry Giscard d'Estaing, the French President, met for confidential, 
informal deliberations on Western security issues. ${ }^{42}$ At the summit, Callaghan took the opportunity to have a private discussion with Carter about the President's attitude to US assistance with the replacement of Polaris. Carter responded positively to Callaghan's inquiries, replying to the Prime Minister that he wished for Britain to remain a nuclear power and that he could see 'no objection' to the supply of Trident $\mathrm{C}_{4}$ with MIRV.43

Carter's forthcoming attitude to the provision of a MIRV system delighted and surprised UK officials. ${ }^{4}$ Given the previous uncertainty about the White House's willingness to provide MIRV, British officials wanted the conversation on-the-record. Subsequently, in late March, Callaghan sent a letter to Carter recapping their conversation in Guadeloupe, and Carter's assurances that he would be 'willing in principle to consider the possibility' of making the Trident $\mathrm{C}_{4}$ MIRVed missile available to the British. 45 However, Carter, in his reply, took a cautionary approach. Carter assured Callaghan of his willingness 'to talk to your people as suggested' but he made no mention of Trident $C_{4}$, and stressed that there should be no presumption about the outcome of the negotiations. ${ }^{46}$ The White House felt it necessary, in drafting this reply, for Carter to take a positive, yet non-committal, stance to Polaris replacement. Despite President Carter's broad support for US assistance with the replacement of Polaris, any Trident agreement was still contingent on further negotiations.

Despite Carter's forthcoming attitude at Guadeloupe, over the course of 1979, the White House procrastinated over the supply of Trident due to the political difficulties it raised for the dual-track decision and the SALT process. Following Margaret Thatcher's victory over 
James Callaghan in the 1979 general election, the US and UK governments arranged preliminary talks on the replacement of Polaris to take place in August 1979.47 In these discussions, US officials expressed support for Polaris replacement. However, alongside this, David Aaron, US Deputy National Security Advisor, emphasised that the administration had made no decision yet on whether they would be willing to transfer MIRV..$^{8}$ Such a 'major step' required 'careful thought'. ${ }^{49}$ Aaron's caution is in marked contrast to the apparent assurances Carter gave Callaghan at Guadeloupe.

The administration had now considered the potential political problems the supply of MIRV could cause. According to current archival declassifications, the White House had not given in-depth consideration to Britain's replacement of Polaris before Guadeloupe and indeed did not expect Callaghan to raise the issue at the summit. $5^{\circ}$ As such following Thatcher's request for the August preliminary talks, Zbigniew Brzezinski, US National Security Advisor, asked the Pentagon to produce two reports, one on US-UK nuclear cooperation and the second on the relationship between the UK's replacement options and wider issues including Theatre Nuclear Force (TNF) modernisation and the SALT process. ${ }^{1}$ Given Aaron's comments, this in-depth consideration had clearly made it apparent that the provision of a MIRV system could provoke a Soviet reaction that might undermine Senate support to ratify the SALT II treaty and hamper Carter's hopes for deep cuts in SALT III.

On 18 June 1979, Carter and Leonid Brezhnev, General Secretary of the Soviet Union, met to sign the SALT II accord. In the summer of 1979, despite vociferous criticism from several quarters, it appeared that the Senate would ratify the treaty. ${ }^{52}$ However, the White House would face an uphill battle in maintaining this narrow majority, due to declining 
support for the SALT process, rising tensions in Soviet-American relations, and an increasing mistrust of Moscow. Indeed, such was the domestic environment, any perceived aggression from the Soviet Union had the potential to terminate Senate ratification. ${ }^{33}$ The provision of a MIRV system to the British could provoke such a Soviet reaction. The Soviets would likely publicly argue, despite the interpretive statement, that the supply of a MIRV system went against the spirit of the non-circumvention clause. Consequently, there was the possibility that the Soviets could react in a way that would heighten feelings of Senate mistrust of Moscow, thus undermining support to ratify the SALT II treaty. The supply could also bolster Soviet arguments that British systems should be included in SALT III due to their increased capability. Concurrently British officials believed that US reservations on the supply of MIRV arose from the 'possible impact of a sharp increase in UK strategic warhead numbers upon the Soviet attitude, especially on deep cuts within SALT III'.54

Events at Guadeloupe had further complicated the supply of a MIRV system. Carter's top priority at the summit was to resolve European concerns over nuclear parity, and Soviet development of SS-20s.55 At Guadeloupe, Carter, Callaghan, Schmidt and Giscard reached agreement on a dual-track solution: NATO would deploy Ground Launch Cruise Missiles and Pershing IIs in Europe, and Washington would propose to open arms control negotiations with Moscow. ${ }^{56}$ The dual-track decision provided implicit justification for US provision of the Trident $\mathrm{C}_{4}$ system. Political reasons, rather than military, motivated US support for Long-Range Theatre Nuclear Force (LRTNF) deployments in Europe.57 The White House hoped that LRTNF modernisation would restore Western confidence in US leadership of the alliance, following the neutron bomb fiasco, and would shore up 
confidence in the viability of NATO's spectrum of deterrence..$^{8}$ These political motivations for LRTNF deployment concurrently provided a rationale for the replacement of Polaris. Within this political thinking, it would have been difficult for the US to refuse Britain a nuclear weapons system that they would, in turn, commit to NATO.

On the other hand, the dual-track decision alongside Polaris replacement could be detrimental to US-Soviet relations. Discussion of LRTNF deployment placed further strain on Superpower relations. Indeed, evidence from the Soviet archives suggests that the dualtrack decision was the 'last drop tipping the scales' prompting Brezhnev to approve the invasion of Afghanistan.59 A decision to deploy LRTNF could heighten Soviet sensitivities about the British and French systems. Following US rebuttal of Soviet demands for the inclusion of British and French systems, as well as US LRTNF, in the SALT process, the Soviets arguably saw the SS-20 as a counterbalance to these systems. ${ }^{60}$ NATO modernisation of LRTNF would obviously concern the Soviets. However, given the context, and the following rationale for developing SS-20s, any talk of replacing Polaris alongside LRTNF modernisation had the potential to cause serious disagreement.

Despite this uncertain political environment, the Thatcher government's concerns over US attitudes on the supply of MIRV were soon negated. On 28 September, US Secretary of State Cyrus Vance told UK Foreign Secretary Lord Peter Carrington that, "he would recommend very strongly to the President that the Americans should make available to the UK the Trident $\mathrm{C}_{4}$ system, including the associated MIRVed technology'. ${ }^{61}$ This firm support from Vance was particularly helpful to the UK government as, following the August preliminary talks, they had determined it to be politically judicious to secure a swift 
agreement on the supply of Trident by the end of December before the White House 'became too pre-occupied' with the 1980 election. ${ }^{62}$

Unfortunately for the British, as their concerns about US willingness to supply Trident $\mathrm{C}_{4}$ with MIRV again abated, Carter's political situation became more problematic. At the end of August, US intelligence agencies 'discovered' a Soviet ground force brigade in Cuba. In fact, there had been a small Soviet training unit stationed on the island since well before the 1962 missile crisis. However, due to a combination of bureaucratic inefficiency and sensitivity on the political right, the 'discovery' created a domestic furore. ${ }^{63}$ The belief that the Soviets had introduced new military units into Cuba fuelled pre-existing doubts that Moscow could not be trusted and further damaged the prospects of SALT ratification. ${ }^{64}$ In addition, as Vance later reflected, the 'political storm' delayed Senate consideration of the treaty 'long enough for it to be overtaken and shelved as a result of the Soviet invasion of Afghanistan'. ${ }^{65}$

The controversy also negatively influenced Moscow's view of Carter. The US President's objection to a small, longstanding, and non-threatening military brigade in an allied country perplexed the Soviet leadership. Further disenchanted and distrustful of Washington, the incident raised Soviet suspicions about the desire, and ability, of the Carter administration to resume détente. ${ }^{66}$ This consequently increased the risk that the Soviets would act in a way Senators would perceive as mistrustful, and hence endanger SALT ratification.

At the same time, the dual-track decision became more problematic politically for the White House. In October, Moscow began a concerted campaign against NATO TNF 
deployments with Brezhnev proposing to discuss arms control of LRTNF, conditioned on NATO reneging on the deployment of new missiles. Concurrently, Soviet officials increasingly argued that their LRTNF were a counter-balance to British and French systems. ${ }^{67}$

The US feared that this propaganda could undermine efforts to achieve alliance consensus on the dual-track approach by December. Trying to gain this consensus had been a difficult task for NATO officials over the course of 1979. The Danish, Dutch, Belgian and Norwegian governments had been deeply hesitant about their states' participation in future deployments of LRTNF and subsequently advocated an arms control solution. ${ }^{68}$ In addition, these NATO Governments, alongside Italy and the Federal Republic of Germany, were reluctant to support a decision that was likely to be extremely unpopular with large sections of their electorate. ${ }^{69}$ Many NATO governments were subsequently concerned that ‘significant political forces in Western Europe' might be responsive to Moscow's suggestion for arms control talks without agreement among NATO to modernise LRTNF. ${ }^{70}$ In turn, this created concern of an intensification of public debate in the Netherlands, which could then spill over into West Germany, Belgium, and Italy and undermine the fragile consensus that was forming. ${ }^{11}$

At this delicate time, any public talk of Polaris replacement could further upset the Soviets and heighten many NATO members' concerns about domestic reaction to dualtrack. Distinctions between strategic and tactical weapons, and the need to modernise both could easily appear academic and nonsensical in public debates. As such, talk of replacing Polaris in addition to LRTNF deployment could stir further public anti-nuclear sentiment. 
These US concerns over SALT ratification and a NATO decision on dual-track subsequently affected White House thinking on Polaris replacement. In October, Brzezinski, Brown and Vance recommended that the President inform Thatcher that he would respond 'affirmatively' to a request for assistance with the replacement of Polaris, including any application for the Trident $\mathrm{C}_{4}$ system. However, they concurrently suggested that the British be asked to delay any 'formal request' for assistance 'until after an alliance decision on TNF and SALT ratification'. ${ }^{72}$ The three men feared that a Polaris replacement deal before the conclusion of these other matters could provide some NATO allies with 'an excuse for not participating in TNF' and the Soviets with 'further incentive to scuttle SALT. ${ }^{3}$ The President subsequently informed Thatcher that he would respond affirmatively to a request for the Trident $\mathrm{C}_{4}$ missile system, but asked for a delay until after Alliance agreement on LRTNF deployment in December. ${ }^{74}$ White House officials also privately affirmed to the British that Carter harboured additional concerns about a transfer interfering with Senate ratification of SALT II. ${ }^{75}$ These US actions clearly display the manner in which SALT, Theatre Nuclear Force modernisation, and Polaris replacement were interconnected. Trident was not a priority in this hierarchy. US actions demonstrated that while the White House supported the replacement of Polaris, they did not prioritise this over intra-alliance relations or arms control efforts.

As the White House only requested a delay to any formal agreement, the US request did not provoke great concern amongst British officials. Indeed, the US commitment to provide a MIRVed $\mathrm{C}_{4}$ brought relief to the Thatcher government, and officials continued to believe that Thatcher would be able to make a formal request in her scheduled December 
meeting with Carter, ready for a public announcement in January. Nevertheless, as British officials were aware, a timely Trident announcement was now reliant on the TNF decision and SALT ratification proceeding as planned..$^{6}$

On 4 November 1979, Carter became embroiled in another foreign policy crisis when Iranian militants stormed the US embassy in Tehran, taking sixty-six Americans hostage. The White House's attempts to secure the hostages' release dominated their foreign policy agenda until the end of Carter's term and severely damaged his already eroding domestic position. 77 By the winter of 1979, Carter's apparent mishandling of foreign affairs was undermining his presidency and threatening re-election hopes. This reinforced Carter's need for a foreign policy success with SALT. Indeed, as David Aaron told the lead British negotiator on Polaris replacement, Robert Wade-Gery, 'It was the "mainspring" of $\mathrm{Mr}$ Carter's Presidency; without it the Presidency would "be destroyed". ${ }^{78}$

Prospects for SALT ratification were looking increasingly difficult. For the Senate to ratify the treaty, most observers believed there would need to be further amendments, which the Soviets would probably dislike. 79 This created issues for the UK's efforts to replace Polaris. The White House feared that at the same time they announced the sale of a Polaris replacement: 'the Russians might well attach a counter-rider insisting that the British deal be abandoned. The President could not survive if SALT II was lost because (as it seemed) he had made the wrong deal... at the wrong moment'. ${ }^{80}$ Subsequently, at the end of November, Aaron informed Wade-Gery that, due to continued difficulties with SALT II, the White House now wished to delay final agreement on the sale of Trident until after the treaty's ratification. ${ }^{81}$ 
Aaron's strong words provoked concern amongst British officials. The White House's wish to postpone an announcement 'to an unsettled date possibly some months in the future', despite NATO's December agreement on dual-track, would create serious problems for the Thatcher Government. ${ }^{82}$ Thatcher's Cabinet Secretary, Robert Armstrong, decried the US position as 'disappointing and unsatisfactory'. He informed Thatcher that, 'we want to get the President firmly and formally committed sooner rather than later; the longer we leave it, the closer we get to the United States election, and the greater is likely to become his reluctance to commit himself.' ${ }^{8} 3$ As such, despite the small chance of success, British officials determined that in her upcoming meeting with Carter on 17 December, Thatcher needed to persuade the President to finalise the Trident agreement within 'weeks rather than months' ${ }^{84}$

Thatcher's efforts at persuasion were unsuccessful. President Carter held firm; any formal request for Trident would have to wait until after the ratification of SALT II. ${ }^{85}$ However, in a glimmer of hope for the British, Carter said that, if Congress failed to ratify SALT II, 'There would then be no obstacle to his agreeing to a request from the United Kingdom Government to a successor to Polaris' ${ }^{86}$ The meeting confirmed to the British that SALT had halted their efforts to secure a Polaris replacement. It was clear that until Carter had his prized treaty ratified or reason to give up on the process entirely, there would be no Trident agreement.

On 24 December 1979, the Soviet Union invaded Afghanistan. The invasion ended any remaining illusion of détente; the US perceived the attack as a determined attempt to gain access to the Persian Gulf and encircle Western oil supplies. Given Carter's domestic 
standing, the President needed to show strength in the face of Soviet aggression. ${ }^{87}$ As part of this, Carter requested the Senate delay consideration of the SALT II Treaty. ${ }^{88}$

These events raised British hopes of securing formal agreement on the sale of Trident. The environment certainly seemed more conducive to the supply of Trident. The invasion led to a further hardening of Carter's foreign policy. With the President refocusing on containment of the USSR, he largely abandoned what was left of his human rights and nuclear non-proliferation policies. ${ }^{89}$ With this downturn in US-Soviet relations, the Carter administration was less concerned about the impact of a Trident deal on future arms control negotiations, such as SALT III..$^{90}$ Furthermore, over the winter of 1979-80, Carter pushed for increased defence spending to modernise US nuclear and conventional forces. ${ }^{91}$ British acquisition of Trident would be a key contribution to this. In this way, the invasion of Afghanistan resulted in the eradication of some of the contradictions between Carter's arms control policies and the sale of Trident, as well as strengthened US reasoning for the deal.

Nevertheless, in early 1980 , despite the indefinite delay of SALT ratification, the White House continued to procrastinate on finalising the sale of Trident. In the aftermath of the invasion, the political problems of Carter increased, and in this environment, the administration was concerned about any potential criticism from the sale of Trident $\mathrm{C}_{4}$. Domestically, Carter was struggling to secure the Democratic nomination for the Presidency and, even if he did so, the Republican front-runner, Ronald Reagan, was ahead of Carter in the opinion polls. ${ }^{92}$ Internationally, Carter's response to the Soviet invasion of Afghanistan was widely criticised as an overreaction. ${ }^{93}$ 
Subsequently, in early February, David Aaron informed Wade-Gery that Carter was still committed to the supply of Trident and no longer saw a connection between the timing of the British request and SALT ratification. However, the President still wished to delay final agreement on the Trident sale as, 'The Administration were [sic] already being accused, domestically and internationally, of over-reacting to the crisis. If they now announced a decision to help us over Polaris replacement, that would be seen as a further and extreme example of over-reaction. It might also be divisive of the Alliance, which was quite badly enough divided as it was.' 94

Due to their concerns over the further delay, over the following month, the British endeavoured to secure a commitment from the US to finalise the sale of Trident. ${ }^{95}$ On 17 March 1980, the White House finally decided that the agreement should be concluded. This decision came even though Brzezinski argued that it 'would be preferable to delay until 1981 ' as the Soviet reaction to the British decision 'could create political complications' for Carter in the run-up to the election. ${ }^{9}$ In response, Vance and Brown argued that, "The British could not count on a 1981 commitment and... even asking the British to wait would create serious concerns in Britain about our commitment, leading to leaks that would be harmful politically and could endanger SALT.'97 Fortunately for the Thatcher government, the President subsequently agreed with Vance and Brown. Finally, the Carter administration had decided to move ahead with the Trident deal. ${ }^{98}$ Ironically, the argument that swayed the White House was the harm that the British reaction could do politically to the administration and SALT with further delay. 
Jimmy Carter's Trident tribulations were finally over. However, this was not due to the resolution of Carter's complex dilemmas around the supply of Trident, including his moral quandary on the provision. 99 Instead, the President's priorities evolved and laid the foundation for Reagan's more aggressive approach. Consequently, the Carter administration now sought to utilise the negotiations over the terms of sale to aid US efforts in the renewed Cold War. In exchange for a reduction in the price of Trident $C_{4}$, the Carter administration sought British commitments on conventional forces and permission to expand the US military base on the UK-controlled island of Diego Garcia. This base was of increased strategic importance to the White House in the aftermath of the invasion of Afghanistan due to the resultant acceleration of plans to enhance US military capability in the Persian Gulf. ${ }^{100}$ Therefore, through the supply of Trident, the Carter administration was able to bolster NATO, in a relatively cheap way, by ensuring the maintenance of Britain's conventional and nuclear forces, and concurrently aid US efforts in the renewed Cold War. In this way, the Carter White House utilised the sale of Trident to reinforce the existing Cold War security architecture and the nuclear order that they had once been determined to modify through arms control.

In November 1980, Ronald Reagan defeated Jimmy Carter in the US Presidential election on a platform of strategic modernisation. Subsequently, in 1981, Reagan decided that the US would replace the Trident $C_{4}$ missile with the more advanced Trident $D_{5}$ by $1989 .{ }^{101}$ At the same time, President Reagan offered the British the option to purchase the $\mathrm{D}_{5}$ instead of the $\mathrm{C}_{4}$, to maintain commonality with the US. ${ }^{102}$ Reagan's forthcoming offer was a stark 
contrast to Carter's procrastination on the supply of a MIRV system, particularly given the D5's advanced capability. The Trident $\mathrm{D}_{5}$ was 'not just a modernised $\mathrm{C}_{4}$ ' but 'a completely new missile'. ${ }^{103}$ Alongside the MX missile, the $\mathrm{D}_{5}$ was at the forefront of US intercontinental ballistic missile technology. It could be MIRVed to fourteen re-entry vehicles per missile; the limit permitted by the provisions negotiated in SALT II. ${ }^{104}$

Yet the decisiveness of Ronald Reagan was not due to his belief in the US-UK nuclear relationship per se. The contrast between Reagan's quick decision and the vacillation of Carter is unsurprising given the Republican's initial approach to the Cold War. Throughout 1981-83, the Reagan administration adopted a highly confrontational policy towards the Soviet Union. ${ }^{105}$ In order to 'blunt and contain Soviet imperialism', Reagan believed that the United States needed to engage in military, political and economic competition with the USSR. ${ }^{106}$ Within this aggressive approach, arms control was a low priority for the Reagan White House, and they were unconcerned about the impact of a British D5 on USUSSR relations.

The events of Reykjavik five years later corroborate that the absence of concern from Reagan over the effect of a $\mathrm{D}_{5}$ sale on US-Soviet relations was due to conceptions of how to 'win' the Cold War rather than support for Britain's nuclear programme per se. In 1986, Reagan nearly reached an agreement with Mikhail Gorbachev, then General Secretary of the Soviet Union, to dismantle all strategic nuclear weapons. ${ }^{107}$ This angered Thatcher due to its potential impact on Britain's nuclear force. Indeed, Michael Jopling, a Cabinet minister who was with her when she was briefed about the summit, 'never saw her more incandescent'. ${ }^{108}$ The elimination of all US strategic nuclear systems would 'have effectively 
killed off the Trident missile' forcing Britain to acquire a non-US system to keep their nuclear programme. ${ }^{109}$

From 1977-82, the evolution of US thinking on détente and arms control influenced the UK's efforts to replace its Polaris nuclear system. Throughout the SALT process, the Carter White House maintained that strategic arms limitation agreements with the Soviet Union would not prevent nuclear cooperation with the UK government. ${ }^{110}$ Relatedly, the precise terms of SALT II did not hinder US-UK nuclear cooperation; this was in part due to the US responding to the concern of its NATO allies, including the UK. Indeed, in a distinct change from the Skybolt crisis and the resultant Polaris sale, there were not powerful elements in the US government reluctant to supply an independent nuclear system to the British. ${ }^{111}$ The administration's attitude towards the US-UK nuclear relationship was one of support or at least acquiescence; the British could have the system they wanted if it did not interfere with the main policy priorities of the Carter White House. It was the political ramifications of supplying Trident $\mathrm{C}_{4}$, particularly due to its MIRV capability, that complicated the UK's efforts to replace Polaris. Whilst the Carter administration expressed support for the continuation of the US-UK nuclear relationship, they vacillated on finalising the terms of the supply of Trident $\mathrm{C}_{4}$ due to their concurrent concerns about the impact of such a sale on NATO cohesion, the SALT process and therefore Carter's political position.

Carter's complex supportive but hesitant attitude towards Trident came from the myriad of challenges that he faced, his lack of coherent strategy in the evolving international environment of the 'long 1970s', as well as the contradictions that existed 
between the different priorities in US foreign policy. ${ }^{112}$ Carter hesitated in part due to the problems that he faced in tackling the issue of strategic parity at a European and international level. With regards to NATO, the supply of Trident ensured the continuation of a second-centre of decision-making on nuclear use, which was helpful in stemming Western European fears over US de-coupling from Europe due to strategic parity. However, the Carter administration also worried that the supply of Trident $C_{4}$ could damage its arms control efforts at the international level. Concurrently the supply of Trident created dilemmas for Carter's non-proliferation aims. On the one hand, the supply of Trident aided efforts to create a managed nuclear order - through the maintenance of a degree of US control and strengthening the US nuclear umbrella in Europe. Yet it also was contentious for East-West diplomacy, and the supply of an advanced system raised moral dilemmas for Carter.

This hesitation on Trident is another example of Jimmy Carter's tendency to vacillate in his foreign policy. ${ }^{113}$ In this case, Carter's vacillation created significant uncertainty for the UK government as they sought to secure agreement on the sale of the Trident $\mathrm{C}_{4}$ system. Yet, the negative ramifications that the Carter White House feared from the supply of Trident mostly dissipated in 1980, due to events external to US-UK nuclear cooperation. This enabled the British to secure a formal agreement on the sale of Trident before Carter became distracted with his re-election campaign; the timing of the Soviet Union's invasion of Afghanistan was fortuitous for the British nuclear programme.

In contrast, the Reagan administration's offer to sell the Trident $\mathrm{D}_{5}$ system was swift - primarily due to Reagan's differing priorities in the Cold War. At this point in his 
Presidency, Reagan did not face the same dilemmas as Carter over the supply of Trident due to his belief that strengthening nuclear and conventional forces, not arms control, was the solution to strategic parity. It will be interesting to see, with further exploration of the archival material, the ways in which Reagan's shift in policy towards arms control after 1983 influenced the US-UK nuclear relationship.

Following the dissipation of Carter's dilemmas over the supply of Trident, the eventual sale of the Trident system reinforced the US-UK nuclear relationship as an accepted part of the global nuclear order, something that still mostly holds today. As such, unlike many other developments in the 'long 1970s', the Trident agreements reinforced the US-led Cold War security architecture. The sale of Trident missiles ensured, via the continuation of the US-UK nuclear relationship, that Britain would remain a significant nuclear power. Both the Carter and Reagan administrations also utilised the agreement to strengthen NATO's nuclear and conventional strength. Yet, as this article has demonstrated, this outcome was not inevitable. The Thatcher government certainly felt a large amount of contingency in the discussions.

\section{NOTE ON CONTRIBUTOR}

Suzanne Doyle is a Lecturer in International Relations at the University of East Anglia. Her research interests include Anglo-American relations, US and British foreign policy, and nuclear studies. 
${ }^{1}$ John Dumbrell, A Special Relationship: Anglo-American Relations from the Cold War to Iraq (Basingstoke: Palgrave Macmillan, 2006), 134-135; Richard Moore, 'Bad Strategy and Bomber Dreams: A New View of the Blue Streak Cancellation', Contemporary British History, 27:2 (2013), 145-166.

${ }^{2}$ Donette Murray, 'Macmillan and Nuclear Weapons: The Skybolt Affair,' in Richard Aldous and Sabine Lee (ed), Harold Macmillan: Aspects of a Political Life (Basingstoke: Macmillan, 1999), 219.

3 Andrew Priest, Kennedy, Johnson and NATO: Britain, America and the dynamics of alliance, 1962-68 (Oxon: Routledge, 2006).

4 See David Sanders, Losing an Empire, Finding a Role: British Foreign Policy since 1945 (Basingstoke: Macmillan, 1990), 190; Kristan Stoddart, 'The Special Nuclear Relationship and the 1980 Trident Decision,' in Jenifer Mackby and Paul Cornish (ed), US-UK Nuclear Cooperation after 50 Years (Washington DC: The CSIS Press, 2008); Ian Clark, Nuclear Diplomacy and the Special Relationship: Britain's Deterrent and America, 1957-1962 (Oxford: Clarendon, 1994), 428; Brian Jamison, 'Completing the Transatlantic Nuclear Bridge: A UK View,' in US-UK Nuclear Cooperation after 50 Years.

5 See John Baylis, 'Exchanging Nuclear Secrets: Laying the Foundations of the AngloAmerican Nuclear Relationship', Diplomatic History, 25:1 (2001), 33-61; John Simpson, The Independent Nuclear State: The United States, Britain and the Military Atom (London: Macmillan, 1983); Thomas Robb, A strained partnership? US-UK relations in the era of détente, 1969-77 (Manchester: Manchester University Press, 2013), 13; Priest, Kennedy, Johnson and NATO, 4; Clark, Nuclear Diplomacy, 2. 
${ }^{6}$ See Barton Bernstein, 'The Uneasy Alliance: Roosevelt, Churchill and the Atomic Bomb, 1940-1945', The Western Political Quarterly 29:2 (1976), 202-320; Murray, 'Macmillan and Nuclear Weapons'; Andrew Priest, 'The President, the “Theologians” and the Europeans: The Johnson Administration and NATO Nuclear Sharing', The International History Review, 22:2 (2011); John Young, 'Killing the MLF? The Wilson Government and Nuclear Sharing in Europe, 1946-66', Diplomacy \& Statecraft, 14:2 (2003); Priest, Kennedy, Johnson and NATO; David Gill, Britain and the Bomb: Nuclear Diplomacy, 1964-1970 (Stanford: Stanford University Press, 2014); Thomas Robb, 'Antelope, Poseidon or a Hybrid: The upgrading of the British Strategic Nuclear Deterrent', Journal of Strategic Studies, 33:6 (2010), 797-817.

7 See Baylis, 'Exchanging Nuclear Secrets', 34; Priest, Kennedy, Johnson and NATO, 4-5; Alan Dobson, Anglo-American Relations in the Twentieth Century: Offriendship, conflict and the rise and decline of superpowers (London: Routledge, 1995), 124-164.

8 Works on the 196os include: Clark, Nuclear Diplomacy; Gill, Britain and the Bomb; Kristan Stoddart, Losing an Empire and Finding a Role: Britain, the USA, NATO and Nuclear Weapons, 1964-197o (Basingstoke: Palgrave Macmillan, 2012); Donette Murray, Kennedy, Macmillan and Nuclear Weapons (Basingstoke: MacMillan, 200o); Priest, Kennedy, Johnson and NATO; Richard Moore, Nuclear Illusion, Nuclear Reality: Britain the United States and Nuclear Weapons, 1958-64 (Basingstoke: Palgrave Macmillan, 2010). Works on the 1970s \& 1980s include: Kristan Stoddart, The Sword and the Shield, Britain, the USA, NATO and Nuclear Weapons, 1970-1976 (Basingstoke: Palgrave Macmillan, 2014); Stoddart, Facing Down the Soviet Union; Helen Parr, 'The British Decision to Upgrade 
Polaris, 1970-4', Contemporary European History 22:2 (2013); John Baylis and Kristan Stoddart, 'Britain and the Chevaline Project: The Hidden Nuclear Programme, 1967-82', Journal of Strategic Studies 26:4 (2003); Robb, 'Antelope, Poseidon or a Hybrid', Journal of Strategic Studies 33:6 (2010); John Baylis and Kristan Stoddart, The British Nuclear Experience: The Role of Beliefs, Culture, and Identity (Oxford: Oxford University Press, 2015).

9 See Stoddart, 'The 1980 Trident Decision', 89-97; Baylis and Stoddart. The British Nuclear Experience; Stoddart, Facing Down the Soviet Union; John Baylis, Anglo-American Defence Relations 1939-1984 (Basingstoke: Macmillan Press, 1984); John Dumbrell, A Special Relationship: Anglo-American Relations from the Cold War to Iraq (Basingstoke: Palgrave Macmillan, 2006).

10 Note of meeting, 1 Dec. 1977, PREM 16/1564, [Kew, United Kingdom] T[he] N[ational] A[rchives].

${ }^{11}$ Ibid.

${ }_{12}$ Ibid; Hunt to Callaghan, 28 Nov. 1977, PREM 16/1564, TNA; Duff-Mason Report, DEFE 24/2122, TNA.

13 Hunt to Callaghan, 28 Nov. 1977, PREM 16/1564, TNA.

${ }^{14}$ Olav Njølstad, 'The collapse of superpower détente, 1975-1980', in Melvyn P. Leffler and Odd Arne Westad (ed), The Cambridge History of the Cold War: Volume III the Endings (Cambridge: Cambridge University Press, 2010), 143; Nancy Mitchell, 'The Cold War and Jimmy Carter,' in The Cambridge History of the Cold War, 74; Jimmy Carter, Why Not the Best? (Nashville: Broadman Press, 1996), 155, 164. 
15 Njølstad, 'The collapse of superpower détente', 143; Mitchell, 'The Cold War and Jimmy Carter', 74; Scott Kaufman, Plans Unraveled: The Foreign Policy of the Carter Administration (De Kalb: Northern Illinois University Press, 2008), 38-39.

${ }^{16}$ Hunt to Callaghan, 28 Nov. 1977, PREM 16/1564, TNA.

${ }_{17}$ 'Terms of Reference for a study of factors relating to further consideration of the future of the United Kingdom nuclear deterrent', Dec. 1978, DEFE 19/275, TNA; Hunt to Callaghan, 7 Dec. 1978, DEFE 19/275, TNA.

${ }^{18}$ John Baylis, 'British Nuclear Doctrine: The 'Moscow Criterion' and the Polaris Improvement Programme', Contemporary British History 19:1 (2005), 53.

19 Duff-Mason Report, Dec. 1978, DEFE 19/275, TNA.

20 'Mr Kingman Brewster's call on the Prime Minister', 18 Nov. 1977, PREM 16/1564, TNA;

Duff-Mason Report, Dec. 1978, DEFE 19/275, TNA.

${ }^{21}$ Daniel Sargent, A Superpower Transformed: The Remaking of American Foreign Relations in the 1970s (Oxford: Oxford University Press, 2016), 236-237.

${ }^{22}$ Francis J. Gavin, 'Strategies of Inhibition: US Grand Strategy, the Nuclear Revolution and Nonproliferation', International Security 40:1 (2015), 19-20, 22; Priest, Kennedy, Johnson and NATO, 25.

${ }^{23}$ Carter to Congress, 28 Nov. 1979, ND-18 1/1/79-12/31/79, Box ND-48, Subject File, White House Central File, [Atlanta, United States of America] J[immy] C[arter] L[ibrary]; Duncan and Brown to Carter, 2 Nov. 1979, Great Britain 10 - 12/79, Box 16, Office File, NSA Brzezinski Material, JCL; Gavin, 'Strategies of Inhibition', International Security 40:1 (2015), 31; Priest, Kennedy, Johnson and NATO, 16. 
24 Duff-Mason Report, Dec. 1978, DEFE 19/275, TNA.

${ }^{25}$ Leopoldo Nuti, 'The Origins of the 1979 dual-track decision - a survey', in Leopoldo Nuti (ed), The Crisis of Détente in Europe: From Helsinki to Gorbachev 1975 - 1985 (Oxon: Routledge, 2009), 62; Kristina Spohr, 'NATO's Nuclear Politics and the Schmidt-Carter Rift,' in Leopoldo Nuti, Frédéric Bozo, Marie-Pierre Rey and Bernd Rother (ed), The Euromissile Crisis and the End of the Cold War (Washington: Woodrow Wilson Center Press), 143; Kristina Spohr Readman, 'Germany and the Politics of the Neutron Bomb, 1975-1979', Diplomacy \& Statecraft 21:2 (2010).

${ }^{26}$ Vance and Warnke, 22 Dec. 1977, NLC-15-114-3-13-2, JCL.

27 Agenda, 17 Nov. 1977, NLC-SAFE-39 D-39-116-15-2, JCL.

${ }^{28}$ Hunt to Callaghan, 28 Nov. 1977, PREM 16/1564, TNA.

29 Hunt to Cartledge, 25 Oct. 1977, PREM 16/1564, TNA.

30 Document 194, 6 Mar. 1978, FRUS 1969-1976, SALT II, 1972-1980, Volume XXXIII.

${ }^{31}$ Duff-Mason Report, Dec. 1978, DEFE 24/2122, TNA.

${ }^{32}$ Ibid.

33 See Baylis and Stoddart, 'Britain and the Chevaline project', 135; Robb, 'Antelope, Poseidon or a Hybrid', 806; Parr, 'The British Decision', 266-269.

34 Olav Njølstad, 'Key of Keys? SALT II and the Breakdown of Détente', in Odd Arne Westad (ed), The Fall of Détente: Soviet-American Relations during the Carter years (Oslo: Scandinavian University Press, 1997), 40; Stephen Millet, 'Forward-Based Nuclear Weapons and SALT I', Political Science Quarterly 98:1 (1983), 79.

35 See Agenda, 17 Nov. 1977, NLC-SAFE-39 D-39-116-15-2, JCL. 
${ }^{36}$ Duff-Mason Report, Dec. 1978, DEFE 24/2122, TNA.

37 Duff-Mason Report, Dec. 1978, DEFE 24/2122, TNA.

38 'Britain's Strategic Nuclear Forces: The choice of a system to replace Polaris', July 1980, DEFE 25/325, TNA.

39 Ibid.

40 Duff-Mason Report, Dec. 1978, DEFE 19/275, TNA.

${ }^{41}$ Note of meeting, 21 Dec. 1977, PREM 16/1978, TNA.

${ }^{42}$ See Kristina Spohr, 'Helmut Schmidt and the Shaping of Western Security in the Late 1970s: the Guadeloupe Summit of 1979', The International History Review 37:1 (2015).

43 'Prime Ministers Conversation with President Carter: 3:30 p.m. 5 January, at Guadeloupe', 5 Jan. 1979, PREM 16/1978, TNA; Callaghan to Healey, 17 Jan. 1979, PREM 16/1978, TNA.

44 Hunt to Thatcher, 18 Jan. 1979, PREM 16/1978, TNA.

45 Callaghan to Carter, 27 Mar. 1979, PREM 16/1978, TNA.

${ }^{46}$ Carter to Callaghan, 3 Apr. 1979, 'Great Britain 6/77 - 12/8o', Plains file, Box 2, JCL.

47 Carter to Thatcher, 8 June 1979, Alpha Channel (Miscellaneous) -- [4/78 - 4/79], Box 20, Subject File, Brzezinski Collection, JCL.

${ }^{48}$ The Situation Room to the President, 17 Aug. 1979, NLC-1-12-1-20-4, JCL.

49 Hunt to Thatcher, 14 Sept. 1979, PREM 19/14, TNA.

50 Western Europe to Brzezinski, ${ }_{15}$ Dec. 1978, NLC-10-17-3-17-1, JCL.

${ }^{51}$ Brzezinski to Vance and Brown, 8 June 1979, Alpha Channel (Miscellaneous) -- [4/78 4/79], Box 20, Subject File, Brzezinski Collection, JCL; these reports remained classified 
when the author visited the Carter Library in June 2013.

${ }^{22}$ Dan Caldwell, 'US Domestic Politics and the Demise of Détente', in The Fall of Détente, 109; Cyrus Vance, Hard Choices (New York: Simon \& Schuster, 1983), 356.

53 Njølstad, 'Key of Keys?', 50-54.

54 Hunt to Thatcher, 14 Sept. 1979, PREM 19/14, TNA.

55 Brzezinski to Carter, 28 Dec. 1978, Box 42, Subject File, Brzezinski Collection, JCL;

Vance to Carter, 20 Dec. 1979, NLC-15-119-6-9-9, JCL.

${ }^{56}$ See Spohr, 'Helmut Schmidt and the Shaping of Western Security'.

57 Raymond Garthoff, Détente and Confrontation: American-Soviet Relations from Nixon to Reagan (Washington, DC: The Brookings Institution, 1985), 859.

${ }^{8}$ See Garthoff, Détente and Confrontation, 853, 859; Joachim Scholtyseck 'The United States, Europe, and the Dual Track Decision', in Matthias Schulz and Thomas A. Schwartz (ed), The Strained Alliance: US-European Relations from Nixon to Carter (New York: Cambridge University Press, 2010), 350.

59 Aleksandr Antonovich Lyakhovsky, 'Inside the Soviet Invasion of Afghanistan and the Seizure of Kabul, December 1979', Cold War International History Project Working Paper \#51 (January 2007), 20.

6o David Holloway, 'The Dynamics of the Euromissile Crisis 1977-1983', in The Euromissile Crisis, 13

${ }^{61}$ Walden to Alexander, 28 Sept. 1979, PREM 19/14, TNA.

${ }^{62}$ Minutes, MISC 7(79) 3rd Meeting, 19 Sept. 1979, CAB 130/1109, TNA.

63 See Westad, 'The Fall of Détente and the Turning Tides of History', in The Fall of 
Détente, 23; Garthoff, Détente and Confrontation, 745, 828-848; Stephanie Freeman, 'The Making of an Accidental Crisis: The United States and the NATO Dual-Track Decision of 1979', Diplomacy \& Statecraft 25:2 (2014), 345-346.

${ }^{64}$ Freeman, 'The Making of an Accidental Crisis', 346; Garthoff, Détente and Confrontation, 829 .

65 Vance, Hard Choices, 358.

${ }^{66}$ Garthoff, Détente and Confrontation, 839, 848.

${ }^{67}$ Sec State to American Embassy Moscow, Oct. 1979, NLC-16-118-4-9-1, JCL.

${ }^{68}$ Kristina Spohr Readman, 'Conflict and Cooperation in Intra-Alliance Nuclear Politics: Western Europe, the United States, and the Genesis of NATO's Dual-Track Decision, 1977-1979', Journal of Cold War Studies 13:2 (2011), 40-43, 76.

69 Vance and Brown to Carter, 9 May 1979, Alpha Channel (Miscellaneous) -- [4/78 4/79], Box 20, Brzezinski Collection, JCL.

70 Special Analysis, 11 Oct. 1979, NLC-7-47-6-4-3, JCL.

${ }^{71}$ Ibid.

${ }^{72}$ Brzezinski to Carter, 15 Oct. 1979, NLC-1-12-7-10-9, JCL.

73 Ibid.

74 Carter to Thatcher, 15 Oct. 1979, Great Britain 6/77 - 12/8o, Box 2, Plains file, JCL.

75 Hunt to Thatcher, 19 Oct. 1979, PREM 19/14, TNA.

${ }^{76}$ Ibid.

77 Mitchell, 'The Cold War and Jimmy Carter', 70.

$7^{8}$ Wade-Gery to Armstrong, 30 Nov. 1979, PREM 19/159, TNA. 
79 Westad, 'The Fall of Détente', 23.

80 Wade-Gery to Armstrong, 30 Nov. 1979, PREM 19/159, TNA.

${ }^{81}$ Ibid.

82 'Prime Minister's Visit to Washington 17 December 1979', 12 Dec. 1979, PREM 19/159, TNA.

${ }^{83}$ Armstrong to Thatcher, 'Future of the Strategic Deterrent (MISC 7)', 4 Dec. 1979, PREM 19/159, TNA.

84 'Prime Minister's Visit to Washington 17 December 1979', 12 Dec. 1979, PREM 19/159, TNA.

85 'Note of a Meeting in the Oval Office', 19 Dec. 1979, PREM 19/159, TNA. 86 Ibid.

${ }^{87}$ Joe Renouard and D. Nathan Vigil, 'The Quest for Leadership in a Time of Peace' in The Strained Alliance, 328; Sargent, A Superpower Transformed, 261.

88 Document 246, 3 Jan. 1980, FRUS 1969-1976, Volume XXXIII, SALT II, 1972-1980.

89 Nancy Mitchell, 'The Cold War and Jimmy Carter,' 87; Sargent, A Superpower Transformed, 288.

90 Schneiter to Cutler group, 12 Feb. 1980, NLC-43-90-1-86, JCL.

${ }^{91}$ Sargent, A Superpower Transformed, 292.

${ }^{92}$ Kaufman, Plans Unraveled, 206.

93 Ibid, 211-213; John Young, 'Western Europe and the end of the Cold War, 1979-1989,' in The Cambridge History of the Cold War, 291; Renouard and Vigil, 'The Quest for Leadership', 326-328. 
94 Wade-Gery to Armstrong, 11 Feb. 1980, PREM 19/159, TNA.

95 Armstrong to Thatcher, 3 Mar. 1980, PREM 19/159, TNA.

${ }_{96}$ Brzezinski to Carter, 18 Mar. 198o, NLC-SAFE 17 D-26 32-11-7, JCL.

97 Ibid.

${ }^{8}$ Ibid.

99 Transcript of interview with Robert Wade-Gery, Interview conducted by Malcolm McBain, 13 Feb. 200o, British Diplomatic Oral History Programme, https://www.chu.cam.ac.uk/media/uploads/files/Wade-Gery.pdf, 88.

${ }^{100}$ Reference deleted to maintain the integrity of the review process; Sargent, $A$ Superpower Transformed, 289.

${ }_{101}$ Thomas to Gilmore, 25 Aug. 1981, FCO 46/2751, TNA.

${ }_{102}$ Thomas to Gilmore, 25 Aug. 1981, FCO 46/2751, TNA; Weinberger to Thatcher, 24 Aug. 1981, PREM 19/417, TNA.

${ }_{103}$ Defence Department, Foreign \& Commonwealth Office, 24 Sept. 1981, FCO 46/2751, TNA.

104 Ibid.

${ }^{105}$ Beth Fischer, The Reagan reversal: Foreign policy and the end of the Cold War (Missouri: University of Missouri Press, 200o), 3.

${ }^{106}$ Allen to Reagan, 14 Sept. 1981, NSCooo21 15 Sept 1981, Box 3, NSC: Meeting Files, [Simi Valley, United States of America] Ronald] Reagan] Library; Chester J. Pach, Jr., 'Sticking to His Guns: Reagan and National Security,' in W. Elliot Brownlee and Hugh Davis Graham (ed), The Reagan Presidency: Pragmatic Conservatism and its Legacies (Lawrence: 
University Press of Kansas, 2003), 85-88; Fischer, The Reagan reversal, 2, 27-28.

107 Cannon, President Reagan, 685-691

${ }^{108}$ Richard Aldous, Reagan \& Thatcher: The Difficult Relationship (London: Random

House, 2013), 221.

109 Ibid.

${ }^{110}$ Hunt to Callaghan, 'The timing of further consideration of the future of the deterrent', 28 Nov. 1977, PREM 16/1564, TNA; 'Consultations with Allies on SALT and Western Security', 2 Mar. 1978, NLC-16-110-7-9-6, JCL; Carter to Callaghan, 27 Apr. 1979, Meetings Vance/Brown/Brzezinski:3/8o - 9/8o, Subject File, Brzezinski Collection, Box 34, JCL. ${ }^{111}$ Priest, 'The Johnson Administration and NATO Nuclear Sharing', The International History Review 22:2 (2011), 26o; Sanders, Losing an Empire, 174; Young, 'Killing the MLF?', Diplomacy \& Statecraft 14:2 (2003), 295.

${ }^{112}$ Mitchell, 'The Cold War and Jimmy Carter', 69; Sargent, A Superpower Transformed, 295 .

${ }^{113}$ See Kaufman, Plans Unraveled, 3-4; Betty Glad, An Outsider in the White House: His Advisors, and the Making of American Foreign Policy (New York: Cornell University Press, 2009); Westad, 'The Fall of Détente'; Mitchell, 'The Cold War and Jimmy Carter', 69. 